\title{
Assessment of disposable groundwater resources for hydraulic fracturing of gas shales in the Lublin Basin (eastern Poland)
}

\section{Introduction}

Natural gas from traditional and unconventional deposits is an important source of energy. Energy forecasts, including natural gas predictions, are discussed by Rychlicki and Siemek (2013). Nagy and Siemek (2011), and Siemek and Nagy (2012) point to the increasing role of gas from unconventional sources and its potential in various areas, Poland included. However, shale gas production requires new and specialized technological solutions, mainly based on the drilling of deep directional boreholes which significantly increases the cost of the production wells (Kaliski et al. 2013), as well as the transport and storage of liquefied gas (Siemek et al. 2011).

Hydraulic fracturing is a method for extracting previously inaccessible natural gas resources, though there are environmental problems related to unconventional gas production. The potential effects on the quality and quantity of groundwater are discussed by Macuda (2010); Macuda and Marchel (2011); Gregory et al. (2011); Osborn et al. (2011); Gordalla et al. (2013); Jackson et al. (2013); Lange et al. (2013); Kissinger et al. (2013); Vidic et al. (2013); Woźnicka (2013); Uliasz-Misiak et al. (2014); Vengosh et al. (2014). Another problem is the amount of water needed for hydraulic fracturing at each of the wells, totaling 7,000-18,000 $\mathrm{m}^{3}$, depending on the geological conditions (Gregory et al. 2011).

* Ph.D., AGH University of Science and Technology, Faculty of Geology, Geophysics and Environmental Protection, Kraków, Poland; e-mail: duda@agh.edu.pl 
It should be born in mind that these figures do not stand for a quantity of water taken during a particular unit of time, but for the amount of water needed for fracturing a well. Prior to the job, the water is stored in a special tank near the drilling pad. The intensity of water production, and consequently the time during which the total volume of water is produced for storing, is arbitrary. It depends on natural hydrogeological conditions in the groundwater intake area and the subjective decision of the concession holder. When the water is extracted at a low rate, the time in which the tank is filled is extended. This volume of water is essentially extracted once for the needs of a single well. However, it can be collected a second time to repeat the fracturing job after a few or a dozen of years of a well's operation with the objective of enhancing gas recovery from the rock.

In the USA, these volumes of water are usually extracted from local groundwater intakes or are obtained from streams in close proximity to shale gas well fields. On the other hand, in regions where natural water resources are limited due to climate and geographic reasons, especially in Texas and its neighbouring southern US states, the reduced availability of water may be an impediment to gas production. Environmental issues appear with regards to water resources and the extraction operations' dependence on increased water intakes (Kargbo et al. 2010; Woźnicka 2013; Uliasz-Misiak et al. 2014; Vengosh et al. 2014). A potential method of addressing both the water supply and environmental challenges is the reuse of treatment water or pretreatment flowback water as the fracturing fluid (Kargbo et al. 2010; Gregory et al. 2011; Woźnicka 2013). This option is connected with practical technological difficulties and, in a majority of cases, high cost - especially given that flowback water has a high concentration of chemical compounds varying considerably in composition (Acharya et al. 2011; Mantell 2011; Cooley and Donnelly 2012; GAO 2012). The Polish economy is oriented toward the lowest gas prices, which may hinder this type of option.

The holders of concessions for shale gas exploitation plan the schedule and magnitude of production; therefore, prior to this planning they need to know the amount of groundwater resources available for gas shale hydraulic fracturing. The evaluation of disposable groundwater resources is a priority because, as drilling practice shows, these are the basic source of water used for fracking jobs (GWPC and ALL Consulting 2009; EPA 2011). This results mainly in water intakes being located in the neighbourhood of the drilling pad, or the purchase of water from local waterworks. Correct evaluation of disposable surface waters resources is more difficult as it requires highly-reliable, long-term hydrological data, frequently regarding small water courses in the drilling pad's vicinity. The flows of these minor water courses often have not been observed at all or only periodically during times when the climate conditions and water intakes differed slightly from the present ones. What is more, due to the high variability of flow, river waters frequently cannot guarantee sufficient amounts of water for fracturing jobs during a specific period of time. Thus it seems that the disposable groundwater resources should be assessed before proceeding.

Apart from the practical relevance, the problem of assessing the forecasted disposable groundwater resources also has a social dimension resulting from public policy requiring a sustainable approach to the future development of the country (Siemek et al. 2013). 
Protecting the good status of the water in groundwater bodies (GWB) and also protecting groundwater in the areas of the main groundwater basins (MGWB) are required by Polish law (Water Act 2001; Szczepański 2013; Woźnicka 2013; Uliasz-Misiak et al. 2014). Owing to their high quality, groundwater resources are mainly used for drinking purposes and by food and pharmaceutical industries (Water Act 2001). Therefore, they should not be used for other purposes, although no such restrictions are stipulated in the Water Act (2001).

The necessity of developing new energy sources in Poland other than hard and brown coal has resulted in the conclusion that eventual Polish shale gas development would be very advantageous in the future, especially considering that no significant renewable energy sources are presently available (Rychlicki and Siemek 2013; Siemek et al. 2013). In Poland, Low Paleozoic shale formations can be encountered in two primary areas - the Baltic Basin and the Lublin Basin (Poprawa 2010; Kiersnowski and Dyrka 2013). However, the preliminarily recognized areas of shale gas and shale oil resources having an industrial potential have turned out to be considerably smaller and more spatially diversified (Kiersnowski and Dyrka 2013). They are mostly located in scarcely populated and poorly developed countryside, agricultural, and forested areas. The groundwater resources in these areas of the Vistula River Basin have been used to a small extent so far (Herbich and Przytuła 2012). Attention should be paid to the fact that water for fracturing purposes is needed over a relatively short time, i.e. only during the time of the job which takes a few days (Veil 2010), and not over the entire production period. Moreover, preliminary data (Kiersnowski and Dyrka 2013) indicate that the nature of fracturing jobs in Poland have to differ from those in the USA due to Poland's different geological conditions and smaller gas resources. In reality, this will mean far fewer drilling pads in Poland. Groundwater in Poland can therefore be treated as a source of water for fracturing gas shales. Importantly, the development of shale gas mining must not raise any ecology-based social conflicts potentially hindering gas extraction (Badera 2010). This requires environmental and social responsibility on the part of industry associated with the production of energy raw materials (Byrska-Rapała 2008; de Melo-Martin et al. 2014).

Thus the concession holders should be allowed no more than the maximum permissible amount of groundwater resources for use in hydraulic fracturing, i.e. the amount which will not deteriorate the state of groundwater and surface water, and which will safeguard water supplies for local communities in the future.

The forecast for groundwater resources in the Vistula River Basin distinguishes, based on the balance for the water catchment area (Herbich and Przytuła 2012), no specific areas that would have a different range than that in the balance catchments. Such specific regions may cover an area of several adjacent concessions for shale gas exploration and exploitation in the Lower Paleozoic Lublin Basin (eastern Poland). This paper proposes a preliminary forecast of guaranteed groundwater resources accessible for shale fracturing in the Lublin Basin in 2030. The year mentioned in the forecast results from the assumption that the development of exploration, recognition, and preparation of industrial gas exploitation across more than 
a dozen concession areas will take about 15 years. This prediction refers to fresh groundwater within GWBs, without stratigraphic division into aquifers.

\section{Assessment of predicted disposable resources}

\subsection{Applied methodology}

Guaranteed groundwater disposable resources $\left(Z_{d g}\right)$ are those resources accessible for environmentally-friendly use when the recharge of groundwater from rainfall infiltration in a drought period lasting several years is low (Herbich and Przytuła 2012). The predicted $Z_{d g}$ in useful aquifers of the Vistula River Basin in the balance catchments was assessed by Herbich and Przytuła (2012). The water management balance of groundwater was determined in reference to water extraction for 2009, which was assumed to represent the current state. The forecast water usage for 2030 is achieved by increasing the current extraction by $15 \%$, accounting only for the extraction from water intakes used on the basis of a water usage permit required by the Water Act (2001). The balance does not take into account the so-called unregistered extraction associated with the regular use of water, which can amount to $5 \mathrm{~m}^{3} / \mathrm{d}$ for the supply of individual households (Water Act 2001). Additionally, the generalised resource balance does not account for several specific factors determining the amount of $Z_{d g}$ in the areas of prospective shale gas production.

\subsection{Modification of resource assessment methodology}

The groundwater can only be extracted to the level of $Z_{d g}$, thanks to which the quantity of groundwater can be maintained at an acceptable level. From 2015, water management in Poland will be subject to verified GWBs (Nowicki 2009; Szczepański and Szklarczyk 2009). In the shale gas concession region of the Lublin Basin there are entirely or partly 12 verified GWBs. The forecast groundwater resources accessible for hydraulic fracturing in the year 2030 were assessed for 12 separate balance zones (BZ), spatially consistent with GWBs or their fragments located within the research area (Fig. 1). Certain relevant numbers have also been assumed in this paper in order to maintain this water management balance model's compatibility with previous numbers and ranges of GWBs as elaborated by Nowicki (2009) in water management in Poland, and the balance areas of groundwater resources elaborated by Herbich and Przytuła (2012).

However, there looms a significant difficulty in this task, characteristic of catchments where shale gas exploitation can be expected in the future. It is not possible to create scenarios of the future water demand and the amount of accessible groundwater resources on the basis of extrapolation of variability trends of individual factors observed in the past. This stems from the following causes: 


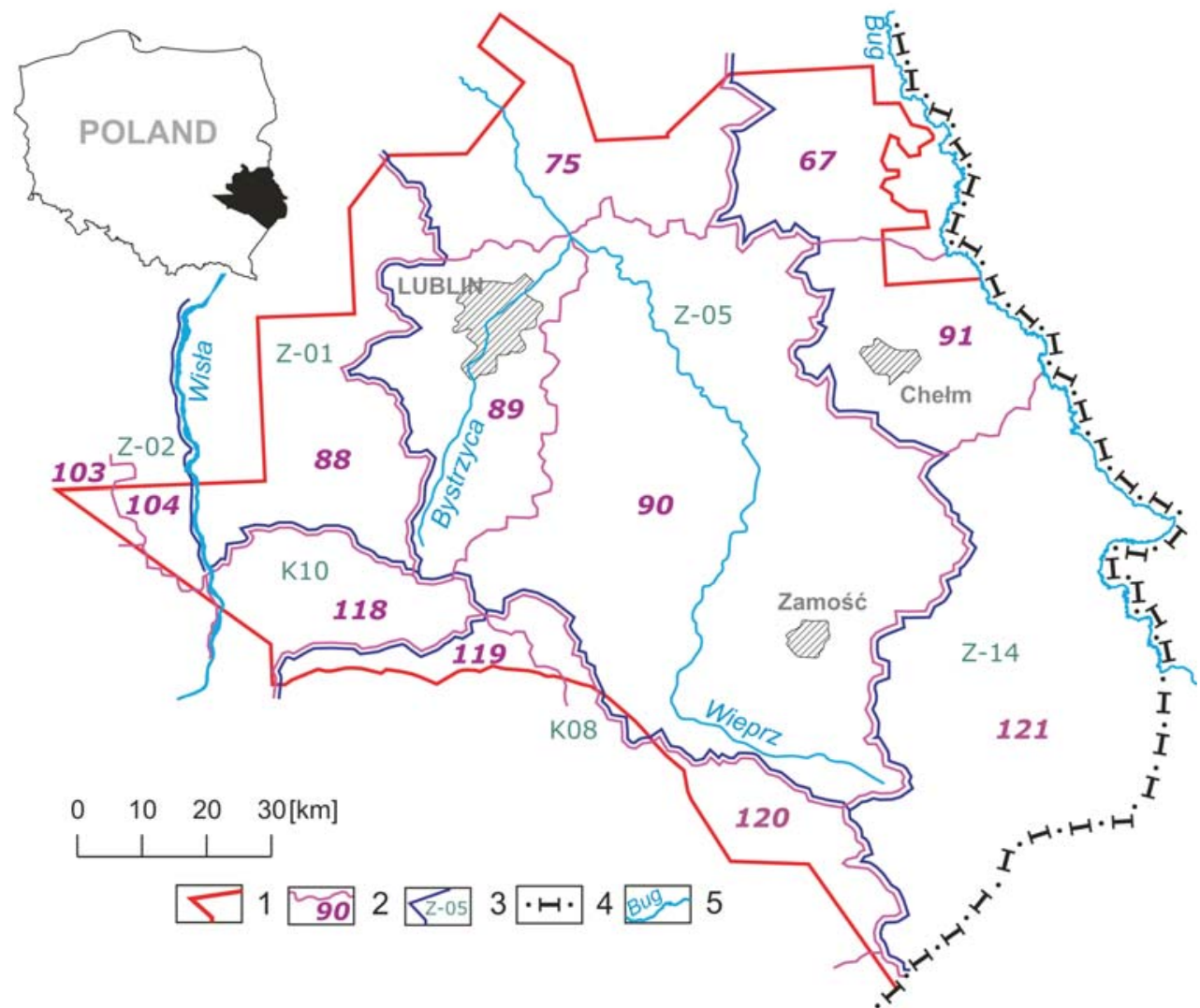

Fig. 1. Balance zones (BZ) in the concession area of the Lublin Basin

1 - the range of the concession area, according to the condition as of 30 April 2013, based on PGI and ME (2013); 2 - the range and number of the BZ, according to the GWBs number by Nowicki ed. (2009); 3 - the range and number of a groundwater balance area, according to Herbich and Przytuła (2012); 4 - Polish border; 5 - main rivers

Rys. 1. Strefy bilansowe (SB) w zasięgu obszaru koncesyjnego basenu lubelskiego 1 - zasięg obszaru koncesyjnego, stan na 30.04.2013 r., na podstawie PGI i ME (2013);

2 - zasięg i numer SB, zgodnie z numerem JCWPd wg Nowicki red. (2009);

3 - zasięg i numer obszaru bilansowego wód podziemnych, zgodnie z Herbich i Przytuła (2012); 4 - granica Polski; 5 - główne rzeki

a) Inevitable global climate changes will result in the successive reduction of the rate of groundwater recharge from rainfall infiltration (Collins et al. 2009; Kossida et al. 2009). This will reduce the volume of renewable groundwater resources. Consequently, $Z_{d g}$ resources will be lower than expected on the basis of the observation of the rainfall amount in the past. The uncertain scale of the decreasing quantity of groundwater recharge from rainfall infiltration may create certain problems when making forecasts; previous models illustrating changes in the volume and structure of rainfall as well as air temperature gave predictions significantly differing in their results. Additionally, 
the models are either large-scale (they do not account for the local climate conditions to an adequate degree) or refer to other regions than the one examined.

b) The degree to which the water demand shall increase in this area in the future is unknown due to the lack of knowledge about the real rate and level of economic and social development - population, degree of water consumption, and savings from the increase in water prices. Additionally, the demand may increase due to the presence of gas mining. However, its extent and intensity, both in time and spatial arrangement, can only be estimated at present.

Another issue making the forecast of the disposable volume of groundwater resources difficult is the assessment of the degree to which water used for hydraulic fracturing recharges. The estimated share of the flowback water recovered from wells depends on geologic conditions, and may range from $10 \%$ to $70 \%$ of the injected fracturing fluid (GWPC and ALL Consulting 2009; EPA 2011). Accordingly, fresh groundwater drawn for the hydraulic fracturing process should be regarded either as partially returnable or practically non-returnable. Additionally, the amount of highly concentrated fluid returning from the well is not equivalent to the amount of fluid that is discharged to a nearby river from the gas mine wastewater pre-treatment installation. This can be attributed to the fact that fluid can be re-injected into the well while wastewater is transported out of the pad or solidified.

The indicated factors may result in the presence of water flows in surface streams smaller than minimum acceptable flows. Ensuring the minimum acceptable flow is essential for maintaining good water quantity status in the river catchments (Gręplowska et al. 2004a; Gręplowska et al. 2004b, Duda et al. 2006). The minimum acceptable flow in a stream is essential for maintaining biological life and for the protection of terrestrial ecosystems dependent on water, including "Natura 2000" sites. In order to account for the uncertainty as to the actual impact of these factors in the year 2030, two scenarios of the water management balance model were prepared. These differ in terms of the pressure exerted on the quantitative status of water as follows:

- Scenario I - moderately rigorous - climatic changes and their consequences are not too great; water demand on the part of the economy and the energy sector are slightly increased, which is associated with the assumed moderate development of shale gas mining and related industries in the research area.

- Scenario II - ecologically rigorous - large climatic changes and their consequences, with a simultaneous radical increase in water demand on the part of the economy and the energy sector in the research area, being a result of intensive gas mining development.

\section{The assessment methodology}

Any undervaluation of the current groundwater extraction may cause the resources to be estimated as more abundant than is actually the case in the research area. In the future, 
this may result in water extraction above the allowed level. In order to ensure that the minimal acceptable flow volume in rivers is not reduced as a consequence of water extraction for hydraulic fracturing, the quantity of corrected current extraction $\left(E_{c c}\right)$ was defined as:

$$
E_{c c}=\left[1+w_{n}-\left(b_{w} \cdot w_{n}\right)\right] E_{a}
$$

where $E_{a}$ is the quantity of the registered current groundwater extraction, $w_{n}$ is the ratio of the volume of the unregistered extraction associated with the usual water utilisation to the registered extraction, $b_{w}$ is the ratio of the amount of water discharged to the river as wastewater to the amount of water drawn in an unregistered manner.

The assessment of the unregistered withdrawal volume being part of the total groundwater extracted is difficult (Frankowski et al. 2008). On the basis of their initial analysis, it was estimated that $w_{n}=0.4$ in the research area, which means that the unregistered withdrawal reaches a level of $40 \%$ of the registered extraction. The assessed quantity is not too low even if the research area comprises mostly rural areas and small towns, which means a large share of individual usage. The loss of water from the water supply network is also taken into account. In Poland it ranges from 18.5\% (Dohnalik 2000) to 50\% (total physical loss from the network and water theft (Frankowski et al. 2008)). Water lost from the water supply network goes back to the shallowest aquifer, thus reducing the actually drawn amount of water.

The value $E_{a}$ is assumed based on Herbich and Przytuła (2012). The value of coefficient $b_{w}=0.75$ is assumed on the basis of the analysis of the supplied water rate of return characteristics given by Herbich and Przytuła, where $b_{w}$ are the estimated values of 0 , 0.25 and 0.75 .

The forecast disposable groundwater resources under natural conditions, i.e. without the extraction through intakes, in particular balance zones $Z_{f(B Z)}$ were calculated as

$$
Z_{f(B Z)}=f \cdot Z_{c}
$$

where $f$ is the share of the surface area of a given zone $\left(F_{B Z}\right)$ of the total surface area of the balance catchment $(F)$ within which a given zone is located, $F$ based on Herbich and Przytuła (2012), i.e.

$$
f=\frac{F_{B Z}}{F}
$$

$Z_{c}$ is the forecast disposable resources reduced in relation to the disposable resources in the water balance areas $\left(Z_{d g}\right)$ as estimated by Herbich and Przytuła (2012) on sequences of long-term data from the second half of the 20th century; $Z_{c}$ is defined by the dependence

$$
Z_{c}=\left[1-\left(c_{i}+b_{f}\right)\right] \cdot Z_{d g}
$$


where $c_{i}$ is the coefficient depending on the degree of decreasing renewable groundwater resources as a result of climate changes, and $b_{f}$ is the coefficient depending on the rate of the groundwater extracted for fracturing return to hydrological circulation of water in the scale of the catchment. If the return of extracted water to hydrological circulation decreases, then coefficient $b_{f}$ increases, causing the calculated prediction of available resources $\left(Z_{s}\right)$ to decrease. The value of coefficient $b_{f}$ is a function depending on $(i)$ the recovery degree of water used for fracking jobs, depending on geological conditions; and (ii) the amount of recuperated fluid discharged into a river as treated effluent.

Bearing in mind that the assumed scenarios of the forecast model are different in terms of the degree of pressure exerted on the water's quantitative status in the catchment balance areas, the appropriate values of coefficients $c_{i}$ and $b_{f}$ were assumed. Given the lack of direct studies and quantitative data on the described correlations at the preliminary stage of predictions, the approximate values of parameters $c_{i}$ and $b_{f}$ were assumed. In the future, the actual values of these parameters should be determined on the basis of separate studies. This also refers to the real volume of groundwater extracted for fracturing purposes.

Scenario I - moderately increased pressures

- $c_{i}=0.05$ due to the assumption of a small decrease in renewable groundwater resources being the result of slight climate changes,

- $b_{f}=0.05$ due to the fact that flowback water, after being used for fracturing in the well, entirely discharged as cleaned effluent to the river, will constitute even $50 \%$ of the water used for fracturing; i.e. it is assumed that the fresh groundwater extraction will be partly hydrologically returnable as a result of the fracturing's geological conditions with the simultaneous presence of sewage treatment plants at gas mines which discharge sewage to the river.

Scenario II - significant increased pressures

- $c_{i}=0.15$ a significant decrease in renewable groundwater resources was assumed, a consequence of the assumed profound effects of climate changes,

- $\mathrm{b}_{f}=0.15$ flowback water, after being used for fracturing, will be discharged as cleaned effluent to the river. This will constitute only $20 \%$ of the water used for fracturing; i.e. it is assumed that the extracted fresh groundwater will be practically non-returnable to the hydrological environment, the fracturing fluid will be retained in the strata, there will be no sewage treatment plants at gas mines, and only waste pits will be formed.

The corrected current groundwater extraction in balance zones $E_{c c(B Z)}$ was calculated analogously

$$
E_{c c(B Z)}=f \cdot E_{c c}
$$

where $E_{c c}$ is the corrected current extraction (2009) in the water balance area (equation 1). 
The forecast degree of disposable groundwater resources utilisation in 2030 in balance zones $(u)$ is determined by the formula

$$
u=\frac{E_{f(B Z)}}{Z_{f(B Z)}}
$$

where $E_{f(B Z)}$ is the forecast water extraction for 2030 in separate balance zones, determined by the dependence

$$
E_{f(\mathrm{BZ})}=d_{s g} \cdot E_{c c(\mathrm{BZ})}
$$

where $d_{s g}$ is the coefficient dependent on factors affecting the withdrawal amount in the future.

For the assumed forecast scenarios, the appropriate values of the coefficient $d_{s g}$ were assumed as follows:

Scenario I - moderately increased pressures

- $d_{s g}=1.2$ an additional extraction of $5 \%$ in relation to the standard assumptions $(15 \%)$ is assumed; this results from the increased economic and social demands associated with moderate shale gas mining development.

Scenario II - significantly increased pressures

- $d_{s g}=1.3$ an additional extraction of $15 \%$ in relation to the standard assumptions $(15 \%)$ is assumed; this results from intensive shale gas mining development.

The forecast guaranteed disposable groundwater resources in the balance zones of 2030 $\left(R_{f(B Z)}\right)$, taking into account the forecast water extraction, are referred to as

$$
R_{f(B Z)}=Z_{f(B Z)}-E_{f(B Z)}
$$

\section{Results and discussion}

The calculations of the predicted guaranteed disposable groundwater resources in the year 2030 in the researched balance zones $R_{f(B Z)}$ for Scenarios I and II are summarised in Tables 1 and 2. The degree of the forecast disposable resources usage in Scenario I will amount to $9 \%$ in zones nos. 119 and 120 , and up to $46 \%$ in zone no. 88 . The reserve of groundwater resources accessible for the development is therefore equal to from $54 \%$ up to $91 \%$, depending on the balance region. In the more environmentally restrictive Scenario II, which assumed high pressure on the water environment, this reserve ranges from $36 \%$ to $88 \%$.

The forecast disposable guaranteed groundwater resources in balance zones will range from $1,072,735 \mathrm{~m}^{3} /$ year in zone no. 103 up to $79,458,310 \mathrm{~m}^{3} /$ year in zone no. 90 for 


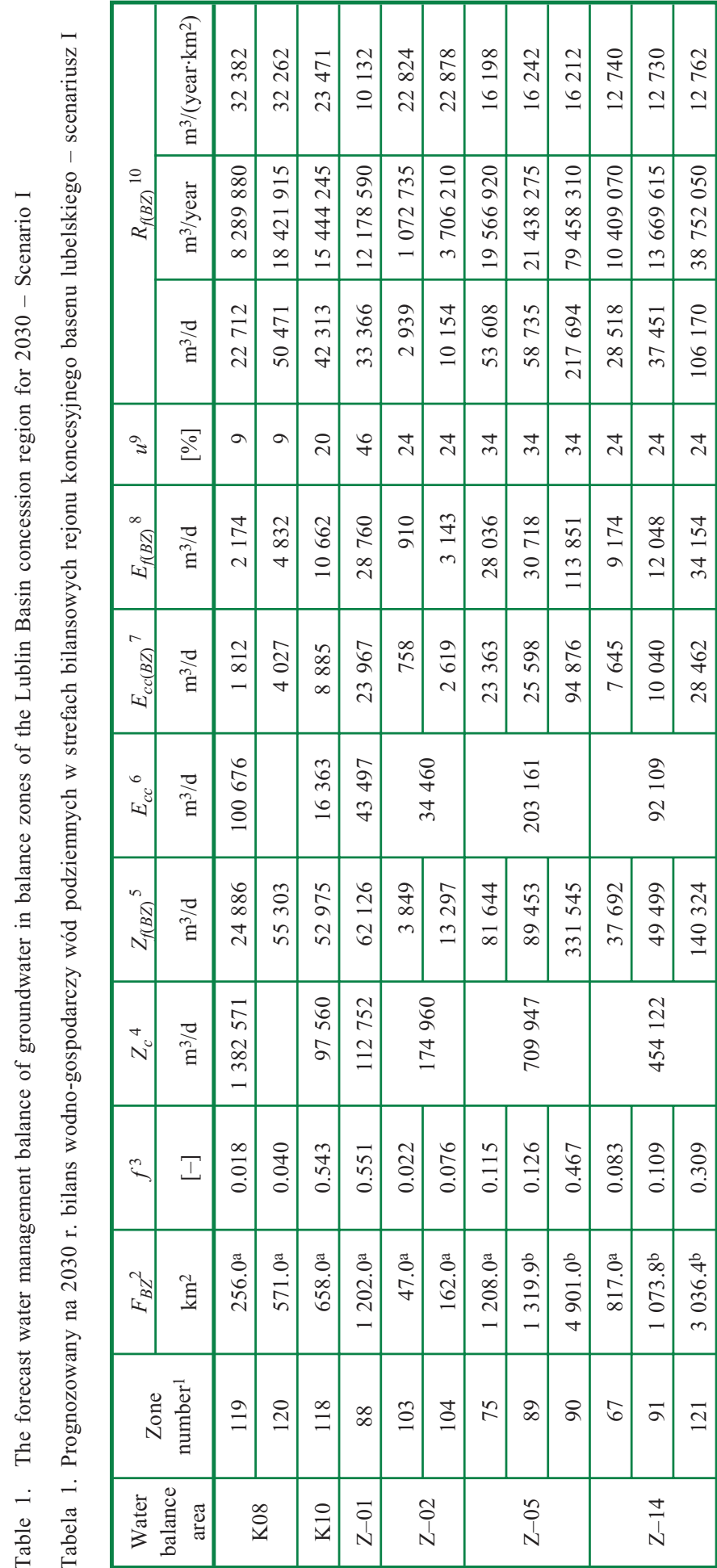

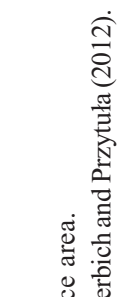

- 造恋

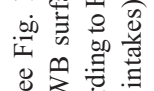

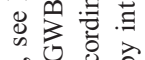

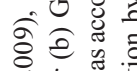

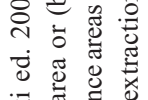

这. 造

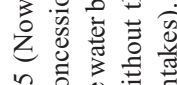

능

ह

ह잉

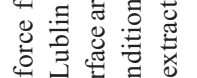

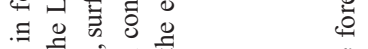

。若过哥

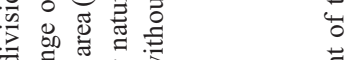

 응

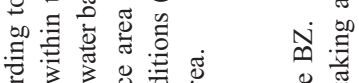

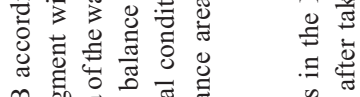

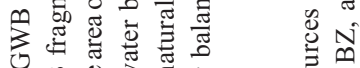

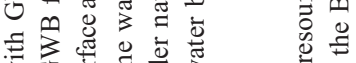

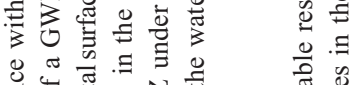

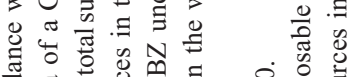

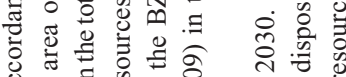

의

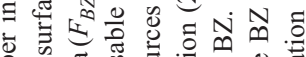

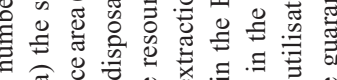

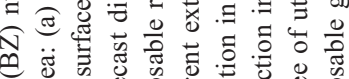

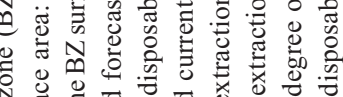

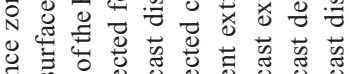

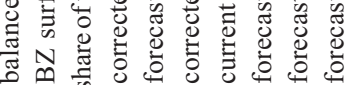

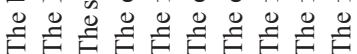

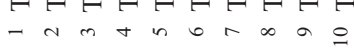




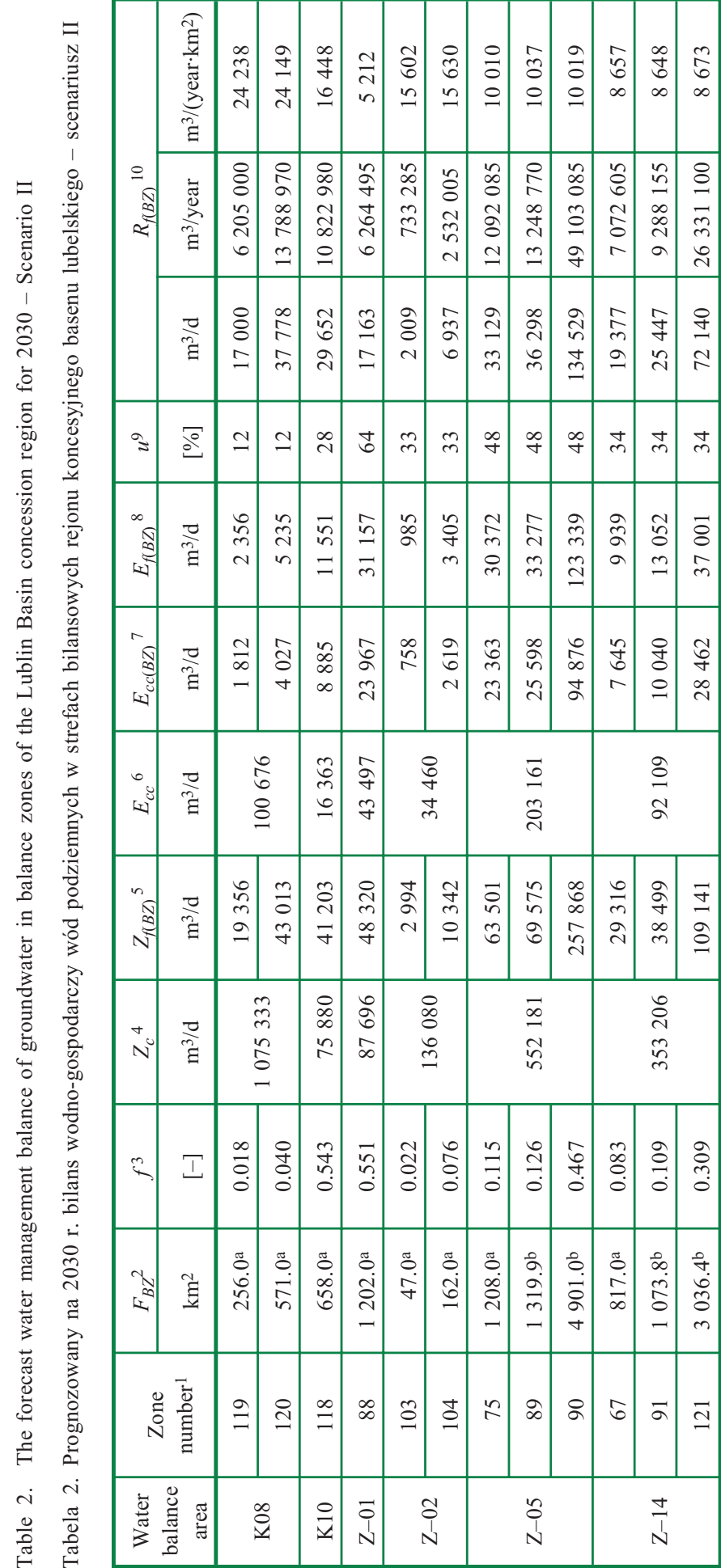

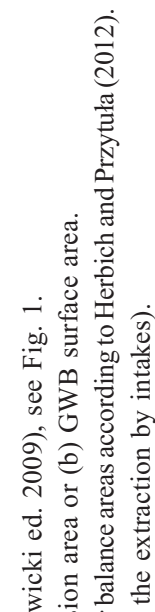

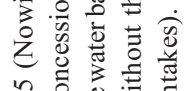

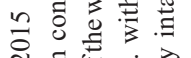

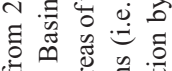

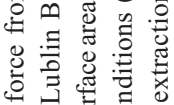

$\stackrel{7}{0}$

$\because$

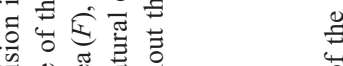

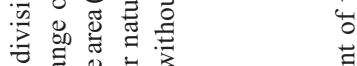

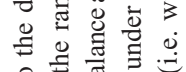

을

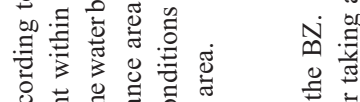

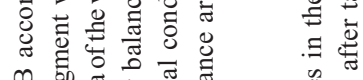

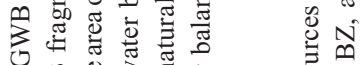

(

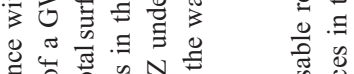

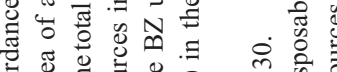

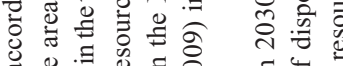

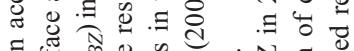

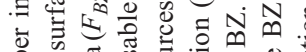

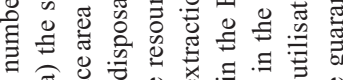

@若

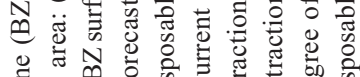

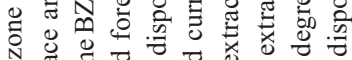

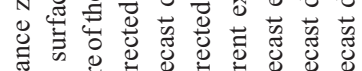

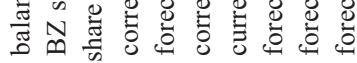

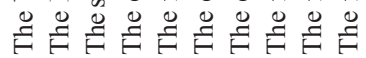


Scenario I. For Scenario II, these resources will amount to $733,285 \mathrm{~m}^{3} /$ year in zone no. 103 and up to $49,103,085 \mathrm{~m}^{3} /$ year in zone no. 90 . The spatial variability of the resources, resulting mainly from the size of a given balance zone area and the variability of the forecast water extraction and hydrogeological conditions between zones affects the diversity of the forecast disposable guaranteed resources between separate zones.

This paper does not aim to compare preliminarily evaluated groundwater resources which are accessible during a given unit of time, together with a strict value of water demand over the same unit of time. The reasons for this are twofold. Firstly, the water demand is unknown at present. This results from the fact that shale gas mining in Poland is currently between the stage of initial geological recognition and the stage of evaluation of industrial resources and economic analysis. It is currently impossible to assess whether or not the groundwater resources will be sufficient during a given period of time. Secondly, the extent of groundwater extraction to fill storage tanks for future fracturing jobs may vary; at the lower withdrawal rate only the time of the operation will be extended. Hence an alternative approach can be proposed in this paper. The concession holders in a given area could adjust their demand to the available groundwater resources. They could schedule their groundwater withdrawals so as not to exceed the disposable groundwater resources for a given unit of time, within the limits of particular concessions. However, in the future, the comparison of preliminarily assessed disposable resources for fracturing purposes can be performed on the basis of data regarding planned water demand within particular concessions and in reference to the periods of planned fracking jobs.

The absolute values of resources in separate zones are necessary for regional boards of water management and local administration offices to control water usage permits issued for groundwater extraction. In order to manage water in a sustainable manner, it is important that the extraction be evenly distributed in the balance zone and that the sum of water quantities resulting from water usage permits does not exceed the disposable guaranteed groundwater resources.

Therefore, the relative values of resources expressed per unit area are important for the holder's concessions for gas exploitation. Knowing the surface area of the concession area, it is possible to determine water resources which can be utilised within particular years of gas production within the concession. The largest unit resources were found in zones nos. 119 and 120, and they amounted to about 32,300 $\mathrm{m}^{3} /\left(\mathrm{year} \cdot \mathrm{km}^{2}\right)$ for Scenario I, and about $24,200 \mathrm{~m}^{3} /\left(\right.$ year $\left.\mathrm{km}^{2}\right)$ for Scenario II. However, the smallest unit resources are encountered within zone no. 88 , amounting to $10,132 \mathrm{~m}^{3} /\left(\right.$ year $\left.\mathrm{km}^{2}\right)$ for variant no. I and $5,212 \mathrm{~m}^{3} /\left(\right.$ year $\left.\mathrm{km}^{2}\right)$ for variant no. II.

Having assumed that the length of the fractured horizontal section of a well is only $1500 \mathrm{~m}$, plus an identical well in the opposite direction, then the side of a square with the drilling pad in the center will be $3000 \mathrm{~m}$ long. This gives an area of $9 \mathrm{~km}^{2}$ around the pad. As assumed in Scenario II of the prediction, with the smallest groundwater resources expressed per $1 \mathrm{~km}^{2}$ (balance zone no. 88), the water withdrawal from an area of $9 \mathrm{~km}^{2}$ can reach $46,908 \mathrm{~m}^{3}$ yearly, i.e. $128 \mathrm{~m}^{3} / \mathrm{d}$. For the biggest groundwater resources (zones nos. 119 and 120) in Scenario II, 217,800 $\mathrm{m}^{3}$ yearly, i.e. $597 \mathrm{~m}^{3} / \mathrm{d}$ of groundwater can be 
extracted from an area of $9 \mathrm{~km}^{2}$. Horizontal sections of the wells do not have to be fractured at the same time. Hence the fracturing schedule can be adjusted to the amount of groundwater withdrawn and stored in the tank for fracking jobs so that the locality is not overexploited. This example has been given to illustrate one of the possible ways in which the predicted values of disposable groundwater resources, evaluated on the basis of the new methodology, can be utilized.

\section{Conclusions}

The preliminary simulation on the presented balance model shows that the forecast, disposable, guaranteed groundwater resources in the balance zones of the Lublin Basin area for 2030 are large; thus the development of shale gas mining should not negatively affect the quantitative water status in this region. This prediction refers to groundwater resources without stratigraphic division into aquifers.

It is advisable to use the proposed methodology for predicting disposable guaranteed resources for balance plots corresponding to ranges of actual concessions for shale gas exploitation in the Lublin Basin, as well as in other prospective areas. Thanks to this approach, the risk of ecologically unsustainable groundwater extraction can be avoided. At the same time, the concession holders will obtain reliable data for planning the size and schedule of gas extraction.

This approach can also be applied in further research work as the balance model can be supplemented with other factors affecting the quantity of groundwater resources - especially in the case of significant differences in hydrogeological, climate, socio-economic conditions, or fracturing technology in other prospective fields, especially in Europe. Its modification is also possible by specifying alternative values of factors determining the volume of guaranteed disposable resources.

The author would like to express his gratitude to the anonymous Reviewers for their valued remarks which significantly contributed to improving the quality of this paper. The research work was supported under the AGH University of Science and Technology Research Program no 11.11.140.026

\section{REFERENCES}

Acharya et al. 2011 - Acharya, H.R., Henderson, C., Matis, H., Kommepalli, H., Moore, B. and Wang, H., 2011. Cost Effective Recovery of Low-TDS Frac Flowback Water for Re-use. US Department of Energy: DE-FE0000784, GE Global Research, $100 \mathrm{p}$

http://www.netl.doe.gov/ file\%20library/Research/oil-gas/FE0000784_FinalReport.pdf [accessed 26 June 2014].

Badera, J. 2010. Konflikty społeczne na tle środowiskowym związane z udostępnianiem złóż kopalin w Polsce. (Social conflicts on the environmental background related to development of mineral deposits in Poland). Gospodarka Surowcami Mineralnymi - Mineral Resources Management 26(1), pp. 105-125 (in Polish) 
Byrska-Rąpała, A. 2008. Geoetyka a społeczna odpowiedzialność przemysłu surowców energetycznych. (Geoethics and social responsibility of energy raw materials industry). Gospodarka Surowcami MineralnymiMineral Resources Management 24(4), pp. 41-52 (in Polish).

Collins et al. 2009 - Collins, R., Kristensen, P. and Thyssen, N., 2009. Water resources across Europe confronting water scarcity and drought. EEA Report No 2/2009, European Environment Agency, Copenhagen, 55 p. http://www.eea.europa.eu/publications/water-resources-across-europe [accessed 12 July 2014].

Cooley, H. and Donnelly, K. 2012. Hydraulic Fracturing and Water Resources: Separating the Frack from the Fiction. Pacific Institute, Oakland, California, 34 p. http://pacinst.org/wp-content/uploads/2013/02/full_report5.pdf [accessed 20 May 2014].

de Melo-Martin et al. 2014 - de Melo-Martin, I., Hays, J. and Finkel, M.L. 2014. The role of ethics in shale gas policies. Science of the Total Environment, 470-471, pp. 1114-1119.

Dohnalik, P. 2000. Straty wody w miejskich sieciach wodociagowych. (Water losses in urban water networks). Instytut Gospodarki Przestrzennej i Komunalnej, Polska Fundacja Ochrony Zasobów Wodnych, Bydgoszcz, 60 p. (in Polish).

Duda et al. 2006 - Duda, R., Paszkiewicz, M., Stach-Kalarus, M., Szczepańska, J., Szczepański, A., Witczak, S. and Zdechlik, R. 2006. Wody podziemne i ich współdziałanie z wodami powierzchniowymi. (Groundwater and surface water interaction) [In:] Nachlik, E. ed., Identyfikacja i ocena oddziaływań antropogenicznych na zasoby wodne zlewni Raby wraz z oszacowaniem ryzyka nieosiagnięcia celów środowiskowych. Wyd. Politechniki Krakowskiej, Ser. Inżynieria Środowiska, Monografia no. 340, Kraków, pp. 108-166 (in Polish).

EPA 2011 - Proceedings of the US Environmental Protection Agency Technical Workshops for the Hydraulic Fracturing Study: Water Resources Management. Arlington, Virginia. EPA 600/R-11/048, US Environmental Protection Agency, Office of Research and Development, Washington, DC, $116 \mathrm{p}$. http://www2.epa.gov/sites/production/files/ documents/HF_Workshop_4_Proceedings_FINAL_508.pdf [accessed 06 August 2014].

Frankowski et al. 2008 - Frankowski, Z., Gałkowski, P., Kapuściński, J., Mitręga, J., Nowicki, K. and Skrzypczyk, L. 2008. Ocena poboru rzeczywistego wód podziemnych w kraju - aspekty ilości, struktury oraz wyzwań metodycznych. (Assessment of the actual extraction of groundwater in the country - aspects of quantity, structure and methodological challenges) Mat. XVII Symp. naukowo-technicznego pt. Zrównoważone gospodarowanie zasobami wód podziemnych na terenach przekształconych antropogenicznie, PZITS o. w Częstochowie, Częstochowa (in Polish).

GAO 2012 - Information on the Quantity, Quality, and Management of Water Produced during Oil and Gas Production. Report GAO-12-156 Energy-Water Nexus, US Government Accountability Office, Washington, DC, 62 p. http://www.gao.gov/products/GAO-12-156[(accessed 10 July 2014].

Gordalla et al. 2013 - Gordalla, B.C., Ewers, U. and Frimmel, F.H. 2013. Hydraulic fracturing: a toxicological threat for groundwater and drinking-water? Environmental Earth Sciences 70(8), pp. 3875-3893.

Gregory et al. 2011 - Gregory, K.B., Vidic, R.D. and Dzombak, D.A. 2011. Water Management Challenges Associated with the Production of Shale Gas by Hydraulic Fracturing. Elements, 7(3), pp. 181-186.

Gręplowska et al. 2004a - Gręplowska, Z., Szczepański, A., Szczepańska, J., Tyszewski, S. and Witczak, S. 2004a. Ocena stanu wód powierzchniowych i podziemnych. (The surface water and groundwater status assessment) [In:] Nachlik, E. ed., Identyfikacja i ocena oddziaływań antropogenicznych na zasoby wodne dla wskazania części wód zagrożonych nieosiagnięciem celów środowiskowych. Wyd. Politechniki Krakowskiej, Ser. Inżynieria Środowiska, Monografia no. 318, Kraków, pp. 88-103 (in Polish).

Gręplowska et al. 2004b - Gręplowska, Z., Szczepański, A., Szczepańska, J., Tyszewski, S., Witczak, S. 2004b. Identyfikacja istotnych oddziaływań w częściach wód powierzchniowych i podziemnych zagrożonych nieosiągnięciem celów środowiskowych. (Identification of significant impacts in the surface water and groundwater bodies at risk of failing to achieve the environmental objectives) [In:] Nachlik, E., ed., Identyfikacja i ocena oddziaływań antropogenicznych na zasoby wodne dla wskazania części wód zagrożonych nieosiagnięciem celów środowiskowych. Wyd. Politechniki Krakowskiej, Ser. Inżynieria Środowiska, Monografia no. 318, Kraków, pp. 104-110 (in Polish).

GWPC and ALL Consulting 2009. Modern Shale Gas Development in the United States: A Primer. Ground Water Protection Council and ALL Consulting for the U.S. Department of Energy, Office of Fossil Energy and 
National Energy Technology Laboratory, Washington, DC, $116 \mathrm{p}$.

http://energy.gov/sites/prod/files/2013/03/f0/ShaleGasPrimer_Online_4-2009.pdf (accessed 06 May 2014).

Herbich, P. and Przytuła, E. 2012. Bilans wodnogospodarczy wód podziemnych z uwzględnieniem oddziaływań $z$ wodami powierzchniowymi $w$ dorzeczu Wisty. (Water management balance of the groundwater taking into account the interactions with surface waters in the Vistula River Basin) Informator Państwowej Służby Hydrogeologicznej, Państwowy Instytut Geologiczny-PIB, Warszawa, 123 p. (in Polish).

http://www.pgi.gov.pl/pl/wydawnictwa-geologiczne-pig-pib/

ksiazki/naukowe-i-metodyczne/4333-bilans-wodnogospodarczy-wod-podziemnych-z-uwzgldnieniemoddziaywa-z-wodami-powierzchniowymi-w-dorzeczu-wisy-2012.html [accessed 05 May 2014].

Jackson et al. 2013 - Jackson, R.B., Vengosh, A., Darrah, T.H., Warner, N.R., Down, A., Poreda, R.J., Osborn, S.G., Zhao, K. and Karr, J.D. 2013. Increased stray gas abundance in a subset of drinking water wells near Marcellus shale gas extraction. Proceedings of the National Academy of Science USA, 110(28), pp. $11250-11255$.

Kaliski et al. 2013 - Kaliski, M., Krupa, M., Rychlicki, S., Siemek, J. and Sikora, A.P. 2013. Estymacje kosztów otworów poszukiwawczych i wydobywczych dla złóż ropy i gazu w basenach geologicznych w Polsce. (Estimations of exploration and production costs for natural gas and oil deposits in geological basins in Poland) Gospodarka Surowcami Mineralnymi - Mineral Resources Management 29(3), pp. 167-178 (in Polish).

Kargbo et al. 2010 - Kargbo, D.M., Wilhelm, R.G. and Campbell, D.J. 2010. Natural Gas Plays in the Marcellus Shale: Challenges and Potential Opportunities. Environmental Science and Technology 44(15), pp. 5679-5684.

Kiersnowski, H. and Dyrka, I. 2013. Ordovician-Silurian shale gas resources potential in Poland: evaluation of Gas Resources Assessment Reports published to date and expected improvements for 2014 forthcoming Assessment. Przeglad Geologiczny, 61(11/1), pp. 639-656.

Kissinger et al. 2013 - Kissinger, A., Helmig, R., Ebigbo, A., Class, H., Lange, T., Sauter, M., Heitfeld, M., Klünker, J. and Jahnke, W. 2013, Hydraulic fracturing in unconventional gas reservoirs - Risks in the geological system, Part 2. Environmental Earth Sciences 70(8), pp. 3855-3873.

Kossida et al. 2009 - Kossida, M., Koutiva, I., Makropoulos, Ch., Monokrousou, K., Mimikou, M., Fons-Esteve, J. and Iglesias, A. 2009. Water scarcity and drought: towards a European Water Scarcity and Drought Network $(W S D N)$. European Environment Agency, Copenhagen, 107 p.

http://icm.eionet.europa.eu/ETC_Reports/GapAnalysis_WSD_13.07.2009_v3.pdf (accessed 20 June 2014).

Lange et al. 2013 - Lange, T., Sauter, M., Heitfeld, M., Schetelig, K., Brosig, K., Jahnke, W., Kissinger, A., Helmig, R., Ebigbo, A. and Class, H. 2013. Hydraulic fracturing in unconventional gas reservoirs - Risks in the geological system, Part 1. Environmental Earth Sciences 70(8), pp. 3839-3853.

Macuda, J., 2010. Środowiskowe aspekty produkcji gazu ziemnego z niekonwencjonalnych złóż. (Environmental aspects of unconventional gas production) Przeglad Geologiczny (58)3, pp. 266-270 (in Polish).

Macuda, J. and Marchel, P. 2011. Oddziaływanie prac wiertniczych na środowisko przy poszukiwaniu gazu łupkowego w Polsce. (Impact of drilling works on environment in search for shale gas in Poland) Wiertnictwo, Nafta, Gaz (28)1-2, pp. 263-271 (in Polish).

Mantell, M.E. 2011. Produced water reuse and recycling challenges and opportunities across major shale plays [In:] Proceedings of the Technical Workshops for the Hydraulic Fracturing Study: Water Resources Management. EPA 600/R-11/048, pp. 49-57.

http://www2.epa.gov/sites/production/files/documents/HF_Workshop_4_Proceedings_FINAL_508.pdf [accessed 10 June 2014].

Nagy, S. and Siemek, J. 2011. Shale gas in Europe: the state of the technology - challenges and opportunities. Archives of Mining Sciences 56(4), pp. 727-760.

Nowicki, Z. ed. 2009 - Charakterystyka geologiczna i hydrogeologiczna zweryfikowanych JCWPd. (Geological and hydrogeological characteristics verified $G W B$ 's). Raport z realizacji zadania Państwowej Służby Hydrogeologicznej, Zadanie 28. Państwowy Instytut Geologiczny-PIB, Krajowy Zarząd Gospodarki Wodnej, Warszawa, 28 p. (in Polish).

http://www.psh.gov.pl/plik/id,5140,v,artykul_5652.pdf [accessed 22 April 2014]. 
Osborn et al. 2011 - Osborn, S.G., Vengosh, A., Warner, N.R. and Jackson, R.B. 2011. Methane contamination of drinking water accompanying gas-well drilling and hydraulic fracturing. Proceedings of the National Academy of Science USA, 108(20), pp. 8172-8176.

PGI and ME 2013 - Mapa koncesji na poszukiwanie gazu ziemnego , shale gas” wg stanu na 30-04-2013 r. (Map of concessions for the exploration of natural gas "shale gas" as of 30-04-2013) aut.: Bonda R., Siekiera D., Szuflicki M., Państwowy Instytut Geologiczny - PIB, Ministerstwo Środowiska, Warszawa (in Polish). http://lupki.mos.gov.pl/gaz-z-lupkow/stan-prac-w-polsce [accessed 20 June 2013].

Poprawa, P. 2010. Potencjał występowania złóż gazu ziemnego w łupkach dolnego paleozoiku w basenie bałtyckim i lubelsko-podlaskim. (Shale gas potential of the Lower Palaeozoic complex in the Baltic and Lublin-Podlasie basins, Poland). Przegląd Geologiczny 58(3), pp. 226-249 (in Polish).

Rychlicki, S. and Siemek, J. 2013. Stan aktualny i prognozy wykorzystania gazu ziemnego do produkcji energii elektrycznej w Polsce. (Current conditions and forecasts of natural gas application in the production of electricity in Poland). Gospodarka Surowcami Mineralnymi-Mineral Resources Management 29(1), pp. 5-15 (in Polish).

Siemek et al. 2011 - Siemek, J., Kaliski, M., Rychlicki, S., Sikora, S., Janusz, P. and Szurlej, A. 2011. Importance of LNG technology in the development of world's natural gas deposits. Gospodarka Surowcami Mineralnymi-Mineral Resources Management 27(4), pp. 109-130.

Siemek et al. 2013 - Siemek, J., Nagy, S. and Siemek, P. 2013. Challenges for sustainable development: the case of shale gas exploitation in Poland. Problemy Ekorozwoju - Problems of Sustainable Development 8(1), pp. 91-104.

Siemek, J. and Nagy, S. 2012. Energy carriers use in the world: natural gas - conventional and unconventional gas resources. Archives of Mining Sciences 57(2), pp. 283-312.

Szczepański, A. 2013. Hydrogeologiczne i prawne uwarunkowania rozpoznawania i eksploatacji gazu łupkowego. (Hydrogeological and legal conditions of prospection and exploration of shale gas) Biuletyn Państwowego Instytutu Geologicznego, 456, Hydrogeologia, XIV/2, pp. 583-587 (in Polish).

Szczepański, A. and Szklarczyk, T. 2009. Metodyczne uwarunkowania wydzieleń JCWPd na przykładzie obszaru RZGW w Krakowie. (Methodological conditions of groundwater bodies distinctions: an example of the Regional Water Management Board in Krakow). Biuletyn Państwowego Instytutu Geologicznego, 436, Hydrogeologia, IX/2, pp. 507-514 (in Polish).

Uliasz-Misiak et al. 2014 - Uliasz-Misiak, B., Przybycin, A. and Winid, B. 2014. Shale and tight gas in Poland legal and environmental issues. Energy Policy 65, pp. 68-77.

Veil, J.A. 2010. Water Management Technologies Used by Marcellus Shale Gas Producers. Report prepared by Argonne National Laboratory, Environmental Science Division, for the US Department of Energy, Office of Fossil Energy. http://www.marcellus.psu.edu/resources/ PDFs/argonnelab.pdf [accessed 11 April 2014].

Vengosh et al. 2014 - Vengosh, A., Jackson, R.B., Warner, N., Darrah, T.H. and Kondash A. 2014. A Critical Review of the Risks to Water Resources from Unconventional Shale Gas Development and Hydraulic Fracturing in the United States. Environmental Science \& Technology, DOI: 10.1021/es405118y

Vidic et al. 2013 - Vidic, R.D., Brantley, S.L., Vandenbossche, J.M., Yoxtheimer, D. and Abad, J.D. 2013. Impact of Shale Gas Development on Regional Water Quality. Science 340(6134), 1235009, DOI: 10.1126/science.1235009.

Water Act 2001 - Ustawa Prawo wodne z dnia 18 lipca 2001 r. Obwieszczenie Marszałka Sejmu Rzeczypospolitej Polskiej z dnia 10 stycznia 2012 r. w sprawie ogłoszenia jednolitego tekstu ustawy - Prawo wodne. Dz.U. 2012, nr 0, poz. 145 (in Polish).

Woźnicka, M. 2013. What could be the impact of shale gas exploitation on the water management? Przeglad Geologiczny 61(11/1), pp. 657-662. 


\title{
OCENA DYSPOZYCYJNYCH ZASOBÓW WÓD PODZIEMNYCH DO SZCZELINOWANIA LUPKÓW GAZONOŚNYCH W BASENIE LUBELSKIM (WSCHODNIA POLSKA)
}

\author{
Słowa kluczowe
}

zasoby wód, wody podziemne, poziomy wodonośne, szczelinowanie, gaz łupkowy,

Basen Lubelski, Polska

\section{Streszczenie}

W pracy dokonano prognozy zasobów wód podziemnych do wykorzystania w celu szczelinowania łupków gazonośnych w obszarze Basenu Lubelskiego w 2030 r. Jest to przydatne właścicielom koncesji na eksploatację gazu do planowania wielkości i harmonogramu wydobycia. W celu określenia dyspozycyjnych zasobów wód opracowano model bilansu wodno-gospodarczego, do którego jako podstawowe dane wejściowe wykorzystano dane z bilansu i prognozy zasobów wód podziemnych dla 2030 r. w dorzeczu Wisły. W modelu uwzględniono specyficzne czynniki determinujące wielkość zasobów wody na obszarach perspektywicznej eksploatacji gazu: zmniejszenie zasilania wód podziemnych w wyniku zmian klimatu, nierejestrowany pobór wody w gospodarstwach indywidualnych, zapotrzebowanie na wodę związane z rozwojem górnictwa gazu łupkowego i stopnień zwrotu do obiegu hydrologicznego wody, wykorzystanej do szczelinowania. W celu uwzględnienia niepewności stopnia oddziaływania tych czynników w 2030 r., model wykonano dla dwóch scenariuszy: umiarkowanie rygorystycznego ekologicznie i rygorystycznego ekologicznie, zakładającego duże skutki zmian klimatu i radykalne zwiększenie zapotrzebowania na wodę. Zasoby dyspozycyjne wód określono dla wydzielonych 12 stref bilansowych, zgodnych obszarowo z Jednolitymi Częściami Wód Podziemnych lub ich fragmentami znajdującymi się w obszarze badań. Prognoza dotyczy zasobów wód podziemnych bez stratygraficznego rozdziału na poziomy wodonośne. Zasoby wyniosą dla scenariusza I od 1072735 do 79458310 m³/rok w zależności od strefy. Dla scenariusza II odpowiednio od 733285 do 49103085 m³/rok. Dla właścicieli koncesji na eksploatację gazu istotne są względne wartości zasobów wyrażone na jednostkę powierzchni, które wyniosą dla scenariusza I od 10132 do $32300 \mathrm{~m}^{3} /\left(\right.$ rok $\left.\cdot \mathrm{km}^{2}\right)$ w zależności od strefy i dla scenariusza II od 5212 do $24200 \mathrm{~m}^{3} /\left(\mathrm{rok} \cdot \mathrm{km}^{2}\right)$. Model bilansowy pozwala stwierdzić, że prognozowane na $2030 \mathrm{r}$. zasoby dyspozycyjne wód podziemnych w strefach bilansowych Basenu Lubelskiego są duże, więc rozwój górnictwa gazu łupkowego nie powinien wpłynąć negatywnie na stan ilościowy wód w tym obszarze. 


\title{
ASSESSMENT OF DISPOSABLE GROUNDWATER RESOURCES FOR HYDRAULIC FRACTURING
} OF GAS SHALES IN THE LUBLIN BASIN (EASTERN POLAND)

\author{
Key words
}

water resources, groundwater, aquifers, hydraulic fracturing, shale gas, Lublin Basin, Poland

Abstract

This paper assesses the groundwater resources for hydraulic fracturing of gas shales in the Lublin Basin in 2030. Such evaluations are useful for gas concession holders who plan the magnitude and schedule of gas production. In order to determine the disposable groundwater resources, a water management balance model was developed. The data from the balance and forecast of groundwater resources for 2030 in the Vistula River Basin were used as basic input data. The model accounts for the following specific factors determining the quantity of water resources in prospective gas exploitation areas: reduced groundwater recharge due to climate changes, unregistered water usage by individual households, demand for water associated with shale gas mining development, and the rate of water utilization for fracturing or returned to hydrological circulation. The extent to which these factors will affect the resources available in 2030 is uncertain. The study therefore analysed two environmental scenarios - a moderately rigorous and a rigorous one - assuming major climate change effects and a radical increase in the demand for water. Disposable water resources were determined for 12 separate balance zones in accordance with groundwater bodies (GWB) or their subsections located in the research area. This prediction refers to groundwater resources without stratigraphic division into aquifers. Depending on the zone, the resources will range from 1,072,735 to 79,458,310 $\mathrm{m}^{3} /$ year for Scenario I, and from 733,285 to 49,103,085 $\mathrm{m}^{3}$ /year for Scenario II. Gas concession holders are interested in relative values of resources expressed per area unit which, depending on the zone, will range from 10,132 to 32,300 $\mathrm{m}^{3} /\left(\right.$ year $\left.\cdot \mathrm{km}^{2}\right)$ for Scenario I, and from 5,212 to $24,200 \mathrm{~m}^{3} /\left(\right.$ year $\left.\cdot \mathrm{km}^{2}\right)$ for Scenario II. The analysis of the balance model reveals that the prediction for guaranteed groundwater resources in the balance zones of the Lublin Basin area in the year 2030 is large; thus development of shale gas mining should not negatively affect the quantity of water in this region. 